\title{
Eruption chronology of the first deciduous teeth in children born prematurely with birth weight less than $1500 \mathrm{~g}$
}

\author{
Cronologia de erupção dos primeiros dentes decíduos em crianças nascidas prematuras com peso \\ inferior a $1500 \mathrm{~g}$ \\ Cronología de erupción de los primeros dientes deciduos en niños nacidos prematuros y con peso al \\ nacer inferior a $1500 \mathrm{~g}$
}

Pedro Garcia F. Neto' ${ }^{1}$ Mário Cícero Falcão

\section{ABSTRACT}

Objective: To describe the eruption chronology of the first deciduous teeth in premature infants with birth weight less than $1500 \mathrm{~g}$ and to compare it according to gender and nutritional status at birth.

Methods: Longitudinal study including 40 low birth weight premature infants of both genders. The tooth was considered erupted when the crown went through the gum and became part of the oral environment. The comparison of the eruption chronology in relation to gender and among children appropriate or small for gestational age was done by Student's t-test, being significant $p<0.05$.

Results: The eruption of the first tooth (teeth) occurred, on average, with 11.0 2.1 months of chronological age and with 9.6 \pm 1.9 months corrected for prematurity. The first erupted teeth were the lower central incisors. The average eruption for males was $9.7 \pm 1.9$ and, for females, $9.5 \pm 1.9$ months, both corrected for prematurity ( $p=0.98)$. The average eruption in children with birth weight appropriate for gestational age was $10.1 \pm 1.4$ months; for small for gestational age, it was 9.4 2.2 , also corrected for prematurity $(p=0.07)$.
Conclusions: The average eruption age of the first teeth, corrected for prematurity, was 9.6 months. Sex and nutritional status at birth did not change the eruption chronology.

Key-words: tooth eruption; dentition, primary; tooth, deciduous; infant, premature.

\section{RESUMO}

Objetivo: Descrever a cronologia de erupção dos primeiros dentes decíduos em crianças prematuras com peso de nascimento menor que $1500 \mathrm{~g}$ e comparar as diferenças entre os sexos e entre a adequação nutricional ao nascimento.

Métodos: Estudo longitudinal com 40 crianças prematuras e de muito baixo peso ao nascer, de ambos os sexos. Considerou-se dente erupcionado no momento em que a coroa atravessou a gengiva e passou a pertencer ao ambiente bucal. A comparação da cronologia de erupção quanto ao sexo e entre as crianças adequadas e não adequadas nutricionalmente ao nascer foi realizada com o teste $t$ de Student, sendo significante $p<0,05$.

Resultados: A erupção do(s) primeiro(s) dente(s) ocorreu, em média, com 11,0 $\pm 2,1$ meses de idade cronológica e com 9,6 $\pm 1,9$ meses de idade corrigida para
Instituição: Faculdade de Medicina da Universidade de São Paulo (USP), São Paulo, SP, Brasil

${ }^{1}$ Faculdade de Medicina da USP, São Paulo, SP, Brasil

\author{
Endereço para correspondência: \\ Pedro Garcia F. Neto \\ Avenida Bernardino de Campos, 562, conjunto 406 \\ CEP 11065-002 - Santos/SP \\ E-mail: pedrogarciafneto@yahoo.com.br \\ Conflito de interesse: nada a declarar \\ Recebido em: 1/8/2013 \\ Aprovado em: 8/10/2013
}


a prematuridade. Os primeiros dentes erupcionados foram os incisivos centrais inferiores. A média de erup-

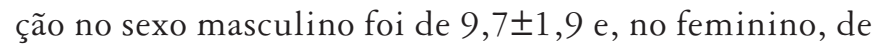
$9,5 \pm 1,9$ meses, ambas corrigidas para a prematuridade $(p=0,98)$. A média de erupção nas crianças adequadas nutricionalmente ao nascer foi de 10,1 $\pm 1,4$ meses e, nas pequenas, de 9,4 42,2 , também corrigidas para a prematuridade $(p=0,07)$.

Conclusões: A idade média de erupção dos primeiros dentes corrigida para a prematuridade foi de 9,6 meses. O sexo e a adequação nutricional ao nascer não alteraram a cronologia de erupção.

Palavras-chave: erupção dentária; dentição primária; dente decíduo; prematuro.

\section{RESUMEN}

Objetivo: Describir la cronología de erupción de los primeros dientes deciduos en niños prematuros con peso al nacer inferior a $1500 \mathrm{~g}$ y comparar las diferencias entre los sexos y entre la adecuación nutricional al nacer.

Métodos: Estudio longitudinal con 40 niños prematuros y de muy bajo peso al nacer, de ambos sexos. Se consideró diente erupcionado en el momento en que la corona atravesó la encía y pasó a pertenecer al ambiente bucal. La comparación de la cronología de erupción respecto al sexo y entre los niños adecuados y no adecuados nutricionalmente al nacer se realizó con la prueba $t$ de Student. El nivel de significancia fue de 0,05.

Resultados: La erupción del (los) primer(os) diente(s) tuvo lugar, en promedio, a los 11,00 $\pm 2,06$ meses de edad cronológica y con 9,61 $\pm 1,91$ meses de edad corregida para la prematuridad. Los primeros dientes erupcionados fueron los incisivos centrales inferiores (81 y 71). El promedio de erupción en el sexo masculino fue de 9,74 $41,91 \mathrm{y}$, en el femenino, de 9,46 $\pm 1,95$ meses, ambas corregidas para la prematuridad $(p=0,98)$. El promedio de erupción en los niños adecuados nutricionalmente al nacer fue de 10,05 $\pm 1,36$ meses y, en los pequeños, de 9,35 $\pm 2,16$, también corregidas para la prematuridad $(p=0,07)$.

Conclusiones: El promedio de edad de erupción de los primeros dientes corregido para la prematuridad fue de 9,61 meses. El sexo y la adecuación nutricional al nacer no alteraron la cronología de la erupción.

Palabras clave: erupción dental; dentición primaria; diente deciduo; prematuro.

\section{Introduction}

The term "eruption" is derived from Latin "erupptione", which means output with momentum. However, the tooth eruption generically known, is one of the stages of a phenomenon that begins with the rupture of the pedicle joining the tooth germ to the dental lamina in the cap stage (odontogenesis) and accompanies the entire life of the enamel organ, going though an intraosseous migration process for the final position in the oral cavity ${ }^{(1)}$. Furthermore, the term "eruption" is used to indicate when the crown of the tooth comes through the gingiva and starts to belong to the oral cavity, i.e., it is only one stage of the physiological process that comprehends a series of movements that teeth perform, from their germ status until the end of their physiological cycle $\mathrm{e}^{(2)}$.

In the context of modern perinatology, the approach of the preterm newborn should be as broad as possible, since the occurrence of problems and deficiencies is common ${ }^{(3)}$. Prematurity may also influence the eruption of deciduous teeth $^{(4)}$. As this phenomenon is related to the physical development, children with lower gestational age, lower birth weight, and more systemic problems would tend to have delayed eruption of the first deciduous teeth. Daily weight gain, age, breastfeeding, inclusion of vitamin supplements, intubation periods, and presence of apnea of prematurity are factors that could interfere with the eruption of primary teeth because these situations are associated to the development of the child ${ }^{(5)}$.

Moreover, the evolution of preterm infants differs from the normal population in two fundamental aspects: the pattern of growth and postnatal development ${ }^{(1)}$. Several factors influence postnatal growth, such as gestational age, nutritional status at birth, nutritional supply, and the intensity and duration of complications ${ }^{(5)}$.

The literature review on the topic demonstrated the concern of researchers regarding the chronology of eruption of deciduous teeth. As studies are methodologically different, including different ethnic groups, the results showed differences related to age and the sequence of tooth eruption, especially in relation to some groups of teeth $^{(4-8)}$. Moreover, such studies include preterm and low weight children, which are distinct groups, since there are term newborns with low birth weight, as well as preterm newborns with birth weight greater than $2500 \mathrm{~g}$. This explains the conflicting results regarding the time and sequence of eruption of primary teeth, as both 
prematurity and low birth weight alone could determine delayed eruption of these teeth. Isolated reports have shown that preterm and very low birth weight children had a significant delay in dental eruption when compared to low weight and normal weight children, particularly before 24 months of age $e^{(6)}$.

This study aimed to describe the chronology of eruption of the first deciduous teeth in preterm infants with birth weight less than $1500 \mathrm{~g}$, besides comparing the chronology of eruption of these teeth between children of both sexes, and between children who received adequate and inadequate nutrition at birth.

\section{Method}

For this study of the chronological eruption of deciduous teeth, we opted for the longitudinal method, i.e., we used the same group of children, who were assessed several times, at predetermined intervals of time until the occurrence of tooth eruption.

The period of data collection was from January 2006 to December 2008 and began when the child was 5 months of age (corrected for prematurity), ending when she presented the eruption of the first deciduous tooth or of the first deciduous teeth, in case of more than one tooth erupted at the same time. This age was also corrected for prematurity. Corrected age is the postnatal age subtracted from the number of days, weeks, or months missing to complete 40 weeks at the time of birth.

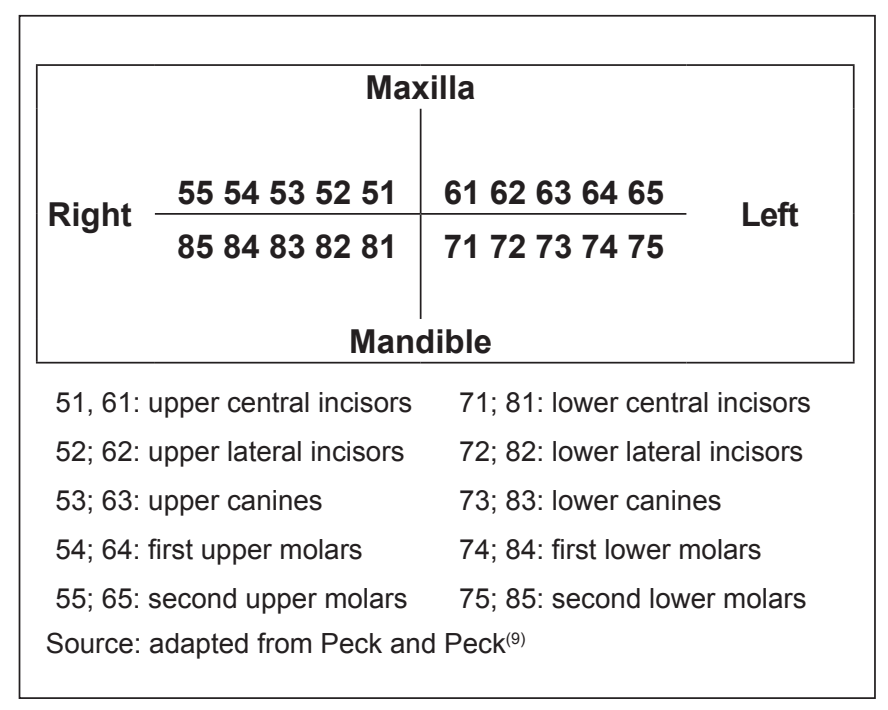

Figure 1 - Nomenclature of deciduous teeth
Data were collected at the High-Risk Infant Outpatient Clinic within the Children's Institute at Hospital das Clínicas da Faculdade de Medicina da Universidade de São Paulo (USP). We started the research after approval by the institution's Research Ethics Committee, under number CAPPesq 981/05, and the signature of the informed consent form by parents and/or guardians.

At each outpatient visit, a clinical examination of the oral cavity of children was conducted. They were positioned supine on the table with mild restraint. The examiner stood in front of the child and the right of the mother to examine the oral cavity, using indirect light to perform the procedure. The same researcher performed all assessments. A tooth was considered erupted from the moment the crown penetrated the gingiva and became part of the oral cavity.

The nomenclature used for primary teeth varies between different authors depending on the time, and older publications mention these teeth with letters or Roman numerals ${ }^{(9)}$. In this study, we have referred the deciduous teeth always using two digits, according to the nomenclature adopted by the International Dental Federation (FDI) and the American Dental Association (ADA), as illustrated in Figure 1.

We used a convenience sample, including children of both sexes, born at the Nursery within the Maternity at Hospital das Clínicas da Faculdade de Medicina da USP, with a gestational age less than 37 weeks and birth weight less than $1500 \mathrm{~g}$. The children were registered at the High-Risk Infant Outpatient Clinic within the Children's Institute and the researcher was present during all outpatient returns.

Exclusion criteria were: major malformations, genetic syndromes, neurological sequelae, multiple births, and abandonment of outpatient follow-up in the period of data collection.

We collected the following data from medical records of the hospital: neonatal sex, birth weight (in grams), length (in centimeters), head circumference (in centimeters) and gestational age.

Regarding the clinical diagnoses of the newborn, we selected nutritional adequacy, considering appropriate for gestational age those falling between the 5 th and the 90th percentiles on the reference curve ${ }^{(10)}$, and the size for gestational age, considering small those newborns below the 5 th percentile and large those situated above the 90th percentile of that curve.

Regarding the outpatient follow-up, we selected the number of appointments at the clinic, weight (in grams), length (in feet), head circumference (in centimeters), body mass index (BMI) at the moment of eruption of the first 
Table 1 - Data of outpatient follow-up until the eruption of primary teeth $(n=40)$

\begin{tabular}{lr}
\hline & Mean \pm DP \\
\hline Number of consultations & $7.2 \pm 1.9$ \\
Weight at eruption $(\mathrm{g})$ & $7.6 \pm 1.2$ \\
Length at eruption $(\mathrm{cm})$ & $68.8 \pm 3.8$ \\
Body mass index at eruption & $16.0 \pm 1.5$ \\
Head circumference at eruption $(\mathrm{cm})$ & $43.6 \pm 2.0$ \\
Age at eruption (months) & \\
$\quad$ Chronologic & $11.0 \pm 2.0$ \\
$\quad$ Corrected for prematurity & $9.6 \pm 1.9$ \\
\hline
\end{tabular}

deciduous tooth or teeth, and age at eruption, considering the chronological age and the age corrected for prematurity.

Data collected from each child, i.e., information regarding the mother, the childbirth, and the neonatal outcome, as well as the outpatient evolution, were compiled on Microsoft ${ }^{\circledR}$ Excel 97 spreadsheets to calculate the mean or median, and the standard deviation. The comparison of the chronology of eruption of the first deciduous teeth between genders and between children who received adequate or inadequate nutrition at birth was performed using Student's t test. The level of significance was established at 0.05 .

SD: standard deviation

Table 2 - Chronology of tooth eruption between male and female children $(n=40)$

\begin{tabular}{|c|c|c|c|c|}
\hline & \multicolumn{2}{|c|}{ Male } & \multicolumn{2}{|c|}{ Female } \\
\hline & \multicolumn{2}{|c|}{$n=18$} & \multicolumn{2}{|c|}{$\mathrm{n}=\mathbf{2 2}$} \\
\hline & Mean & DP & Mean & DP \\
\hline Birth weight $(\mathrm{g})$ & 1129 & 201 & 1169 & 267 \\
\hline Birth Length $(\mathrm{cm})$ & 37.2 & 2.6 & 37.2 & 3.0 \\
\hline Head circumference at birth $(\mathrm{cm})$ & 26.3 & 1.7 & 26.9 & 2.4 \\
\hline Gestational age (weeks) & 30.3 & 2.2 & 31.4 & 2.1 \\
\hline Body mass index (birth) & 8.5 & 0.7 & 8.3 & 0.9 \\
\hline Eruption (chronological age) ${ }^{*}$ & 12.0 & 2.0 & 11.0 & $2.0^{*}$ \\
\hline Eruption (corrected age) ${ }^{*}$ & 9.7 & 1.9 & 9.5 & $1.9^{*}$ \\
\hline Weight at eruption (g) & 7864 & 1069 & 7339 & 1321 \\
\hline Length at eruption $(\mathrm{cm})$ & 69.5 & 3.4 & 68.0 & 4.2 \\
\hline Head Circumference at eruption $(\mathrm{cm})$ & 44.1 & 1.9 & 42.9 & 2.0 \\
\hline Body mass index at eruption & 16.2 & 1.2 & 15.8 & 1.7 \\
\hline
\end{tabular}

SD: standard deviation; *male versus female: Student's $t$ test $p>0.05$

Table 3 - Chronology of eruption of the first deciduous teeth between children with adequate and inadequate neonatal nutrition ( $\mathrm{n}=40$ )

\begin{tabular}{|c|c|c|c|c|}
\hline & \multicolumn{2}{|c|}{$\begin{array}{c}\text { Adequate for } \\
\text { Gestational age } \\
n=15\end{array}$} & \multicolumn{2}{|c|}{$\begin{array}{c}\text { Small for } \\
\text { Gestational age } \\
n=25\end{array}$} \\
\hline & Mean & DP & Mean & DP \\
\hline Birth weight (g) & 1279 & 140 & 1119 & 250 \\
\hline Birth length (cm) & 38.4 & 2.1 & 36.4 & 2.9 \\
\hline Head circumference at birth $(\mathrm{cm})$ & 27.5 & 1.9 & 27.1 & 2.1 \\
\hline Gestational age (weeks) & 31.2 & 2.2 & 31.8 & 2.1 \\
\hline Body mass index at birth & 8.6 & 0.4 & 8.3 & 0.9 \\
\hline Eruption (chronological age) ${ }^{\star}$ & 12.0 & 0.1 & 11.0 & $0.2^{\mathrm{a}}$ \\
\hline Eruption (corrected age) $)^{*}$ & 10.0 & 1.4 & 9.4 & $2.2^{* b}$ \\
\hline Weight at eruption (g) & 8057 & 100 & 7370 & 125 \\
\hline Length at eruption (cm) & 70.9 & 3.0 & 67.6 & 3.7 \\
\hline Head circumference at the eruption $(\mathrm{cm})$ & 44.1 & 1.7 & 43.2 & 2.2 \\
\hline Body mass index at eruption & 16.0 & 1.2 & 16.0 & 1.6 \\
\hline
\end{tabular}

SD: standard deviation; *adequate versus small for gestational age: Student's $t$ test ${ }^{\mathrm{a}} p=0.009 ;{ }^{\mathrm{b}} p=0.07$ 


\section{Results}

During the period of data collection, we selected 46 children who met all inclusion criteria and showed no exclusion criteria. Six were excluded a posteriori by non-attendance at the outpatient appointment at the time of eruption of the first primary tooth.

The summary of the results is presented in the tables, where it is observed that, at the moment of the eruption, the average weight was $756 \mathrm{~kg}$, length $68.80 \mathrm{~cm}$, and the age corrected for prematurity, 9.61 months. These data are demonstrated in Table 1, which shows the data of outpatient follow-up until the eruption of the first deciduous tooth/teeth.

Table 2 shows the comparison of the chronology of tooth eruption between the sexes, with an average weight at the eruption of 77.86 and $7.34 \mathrm{~kg}$, respectively, in males and females.

Table 3 compares the chronology of eruption of the first deciduous teeth between children who received adequate nutrition at birth and those who did not. The average weight at the eruption was $8.06 \mathrm{~kg}$ in children who received adequate nutrition, and $7.37 \mathrm{~kg}$ in those who did not receive adequate nutrition.

Among all studied children, the first eruption was that of the lower central incisors $(81 / 71)$, with tooth 81 (lower right central incisor) in five (12.5\%), and tooth 71 (lower left central incisor) in seven (17.5\%), simultaneous eruption occurred in 28 children (70\%).

Although not part of the study design, it is interesting to note that, when examining the tooth enamel of children who participated in this research, no localized changes were observed due to possible trauma caused by orotracheal intubation or orotracheal tubes.

\section{Discussion}

Children born weighing less than $2500 \mathrm{~g}$ are defined as low birth weight and those with weight lower than $1500 \mathrm{~g}$, as very low birth weight. There are numerous causes for low birth weight, and prematurity, defined by a gestational age less than 37 weeks, is one of the main reasons. It was observed that low weight children have dental delay according to lower weight, length, and head circumference at birth, and may also present delayed motor skills ${ }^{(7)}$. This could indicate that the eruption of primary teeth in premature children would follow a pattern of development itself and, after 2 years, the "normal" pattern would be established ${ }^{(7)}$.

Prematurity and low birth weight may also bring reflexes in the eruption of deciduous teeth. Since these conditions relate to a reduced physical development, children with lower gestational age, lower weight, and more systemic problems would tend to have a delayed eruption of the first deciduous teeth ${ }^{(4)}$. The daily weight gain, the age, the inclusion of vitamin supplements, the duration of intubation, and the presence of apnea of prematurity, as mentioned in the introduction, are factors that could interfere with the eruption of primary teeth because these situations are associated with child development ${ }^{(1)}$.

Like other tissues and organs of the body, facial bones and dentition may be affected by prematurity. Most studies on oral defects have shown that preterm births can cause enamel defects, classified according to the quantitative loss of enamel (hypoplasia), the qualitative change in the translucency (opacity) of enamel, or a combination of both. Such effects generally occur on the first teeth, which are undergoing mineralization at the time of preterm birth, although even the permanent teeth may be affected. The pathogenesis is considered multifactorial, being the most important factor related to calcium disorders in the neonatal period. In addition, delayed eruption and defects in the development of both permanent and deciduous dentitions were also reported ${ }^{(11)}$.

Having outlined the reasons for the importance of the study of the chronology of eruption of deciduous teeth, other aspects may be considered, such as the relative scarcity in the literature about this eruption in preterm children, noting that this group (preterm and very low birth weight) was not properly explored in several studies analyzed. For this purpose, we tested the hypothesis that both prematurity and weight deficit would act to delay the deciduous tooth eruption. In the situation where the two conditions coexist, i.e., prematurity and very low birth weight, this delay could be even greater. Furthermore, conditions that determine an inadequate nutrition and a lower calcium uptake, such as restricted intrauterine growth, being small for gestational age, exclusive parenteral nutrition, and metabolic bone disease, may further change the magnitude of delayed eruption of deciduous dentition ${ }^{(5,7,11)}$.

Adequate birth weight is one of the most important variables for survival, growth, and psychosocial development; furthermore, more than $60 \%$ of mortality in children without chromosomal defects is attributed to low birth weight ${ }^{(12)}$. 
Preterm infants have the disadvantage that their organs are immature, which provides high risk for the development of respiratory diseases, hyperbilirubinemia, hypocalcemia, anemia, and other diseases that affect their health and development. The lower the gestational period, the more frequent and more severe these diseases are. Moreover, the evolution of preterm infants differs from the evolution of the normal population in two fundamental aspects: the pattern of growth and postnatal development ${ }^{(6)}$.

Viscardi $e t a l^{(8)}$ studied children with low birth weight or gestational age less than 37 weeks and showed that this group presents a greater likelihood of delayed eruption of the first tooth, even with chronological age adjusted for prematurity. The authors also reported that, in healthy premature infants, the first tooth erupts at the appropriate chronological age, but the eruption may be delayed in children who required prolonged mechanical ventilation or received inadequate neonatal nutrition. However, the difference between normal and delayed eruption and the contribution of other neonatal factors were not studied. In the present study, the analysis of the results of 40 children born with birth weight less than $1500 \mathrm{~g}$ and gestational age less than 37 weeks shows that the eruption of the first deciduous tooth/teeth occurred on average at 11 months of chronological age and 9.61 months of age corrected for prematurity.

Regarding the age at the eruption, it can be considered that, even when correcting for prematurity, there was a delay when compared to the average eruption in five Brazilian studies about the chronology of eruption in term infants (9.6 versus 8.3 months) ${ }^{(13-17)}$. It is worth mentioning that the value of 8.3 months expresses the mean age of eruption of teeth 81 and 71, i.e., the lower left and right central incisors, respectively. Another important piece of evidence analyzed was the sequence of eruption of deciduous teeth. In this study, all children presented as the first eruption or eruptions the mandibular central incisors (81/71), and in 28 children (70\%), there was concomitant eruption of these two teeth. These findings agree with other studies, in which the sequence found in ascending order, was: lower central incisors, and then, upper central incisors ${ }^{(13-17)}$.

In Brazil, some studies with term infants found an early eruptive process in females ${ }^{(14,18-20)}$. Other studies, also conducted with children born at term, found early eruption for male children $^{(17,21,22)}$. In this study, the average eruption for females was 11 months and, for males, 12 months. When corrected for prematurity, the average was 9.5 months for females and 9.7 months for males, and there was no difference regarding the time of the eruption both for chronological age $(p=0.90)$ and for age corrected for prematurity $(p=0.98)$. The results of this study corroborate the findings of studies that found no significant differences between sexes ${ }^{(15,23,24)}$.

In the present sample, when comparing the mean age of eruption of the first deciduous teeth in relation to nutritional adequacy at birth (Table 3), i.e., when comparing the age of eruption for the children with adequate neonatal nutrition and those small for gestational age, we obtained an average of 12 months of chronological age for adequate nutrition and 11 months for inadequate nutrition, with a significant difference $(p=0.009)$. However, in the case of corrected age for prematurity, the mean of adequate nutrition was 10.1 months, and for inadequate, 9.4 months, with no statistical difference $(p=0.07)$.

Finally, in this series of preterm and very low birth weight children, the average age of eruption of the first deciduous teeth was 11 months for chronological age and 9.6 months for the age corrected for prematurity. Although it was not the object of the study, when comparing tooth eruption in this group of children with the Brazilian mean age of children born at term, there is a relative delay (9.6 versus 8.3 months). These results are similar to those on the systematic review by Paulsson $e t \mathrm{al}^{(11)}$, which have shown a delay in dental development and eruption of preterm children regarding the chronological age. However, if the age corrected for prematurity is considered, there is no delay in dental development and eruption compared to children born at term ${ }^{(11)}$. There was no difference in the comparison between the mean age of eruption of the first deciduous teeth regarding gender both in relation to chronological age and in the age corrected for prematurity. The comparison between the mean age of eruption of the first deciduous teeth and nutritional adequacy at birth showed delayed chronological age of eruption in children who were small for gestational age; however, this delay was not confirmed when the eruption age was corrected for prematurity.

It is noteworthy that this study presents certain limitations for using a convenience sample, in which differences not statistically significant may be due to the lack of statistical power of the sample, besides the fact that we did not use a multivariate model, with adjustment for confounding variables.

Finally, it is noteworthy that hereditary and individual factors, such as sex and race, associated with external factors, such as geographic location, socioeconomic status, nutrition, pregnancy problems, and severe maternal illness can cause differences in patterns of eruption. 


\section{References}

1. Corrêa MS, Martins AL, Fazzi L, Fazzi R. Erupção dentária. In: Corrêa MS, editor. Odontopediatria na primeira infância. São Paulo: Santos; 1998. p. 117-29.

2. Guedes-Pinto AC. Odontopediatria. $7^{\text {th }}$ ed. São Paulo: Santos; 2003.

3. Aguiar SM, Castro AM, Barbieri CM. Alteração dentária em crianças nascidas prematuras: revisão de literatura. J Bras Odontopediatr Odontol Bebe 2003;6:240-3.

4. Duarte ME, Andrade MA, Faria PC, Marques LS, Jorge ML. Fatores associados à cronologia de erupção de dentes decíduos - revisão de literatura: erupção de dentes decíduos e fatores associados. Rev Univ Vale Rio Verde 2011;9:139-51.

5. Seow WK. Effects of preterm birth on oral growth and development. Aust Dent J 1997;42:85-91.

6. Ramos SR, Gugishi RC, Fraiz FC. The influence of gestational age and birth weight of the newborn on tooth eruption. J Appl Oral Sci 2006;14:228-32.

7. Fadavi S, Punwani IC, Adenis S, Vidyasagan D. Eruption pattern in primary dentition of premature low-birth-weight children. J Dent Child 1992;59:120-2.

8. Viscardi RM, Romberg E, Abrams RG. Delayed primary tooth eruption in premature infants: relationship to neonatal factors. Pediatr Dent 1994; 16:23-8.

9. Peck S, Peck L. Tooth numbering progress. Angle Orthod 1996;66:83-4.

10. Alexander GR, Himes JH, Kaufman RB, Mor J, Kogan M. A United States national reference for fetal growth. Obstet Gynecol 1996;87:163-8.

11. Paulsson L, Bondemark L, Söderfeldt B. A systematic review of the consequences of premature birth on palatal morphology, dental occlusion, tooth-crown dimensions, and tooth maturity and eruption. Angle Orthod 2004;74:269-79.

12. Oliveira LC, Temponi K, Caúla AL, Barboza EP. A doença periodontal nas gestantes é um fator de risco para o parto prematuro e/ou baixo peso do recém nascido? Rev Periodontia 2003;13:39-43.
13. Aguirre AL, Rosa JE. Sequência de erupção dos dentes das crianças de Florianópolis. Odontol Mod 1988;15:34-7.

14. Vono AZ. Estudo da cronologia e sequência de erupção dos dentes decíduos em crianças leucodermas, brasileiras, de Bauru, Estado de São Paulo [tese de doutorado]. Bauru (SP): USP; 1972.

15. Andrade IR, Bezerra AC. Estudo longitudinal comparativo da cronologia de erupção em crianças. J Bras Odontopediatr Odontol Bebe 1998;1:41-7.

16. Berzin NF, Soriano G, Lema AF. Sequência e cronologia eruptiva de dente decíduos de crianças carenciadas sócio economicamente. Rev Bras Odontol 1990;47:41-4.

17. Oliveira LU, Freitas JA, Abdo RC, Weber J. Estudo da cronologia de erupção de dentes decíduos em crianças leucodermas, nascidas e residentes em Santa Maria, Estado do Rio Grande do Sul. Odontol Mod 1987;14:6-19.

18. Tamburús JR, Conrado CA, Campos SM. Chronology and sequence of the primary tooth eruption. A Longitudinal Study. Rev Farm Odontol 1977;14:23-33.

19. Carvalho MMP, Sampaio MC, Issao M. Cronologia e sequência de erupção de dentes decíduos de crianças nutridas e desnutridas da Grande João Pessoa, Paraíba. Rev Paul Odontol 1992;14:10-6.

20. Menezes ICB, Peters CF. Contribuição ao estudo da cronologia e sequência de erupção dos dentes decíduos. Enc Bras Odonto 1983;4:25-32.

21. Bönecker MJ, Ferreira SL, Birman E. Prevalence of dental anomalies in children aged 0 to 36 months. J Bras Odontopediatr Odontol Bebe 2002;5:425-31.

22. Haddad AE. Cronologia e sequência de erupção dos dentes decíduos em crianças de 0 a 36 meses de idade no município de Guarulhos - São Paulo [tese de mestrado]. São Paulo (SP): USP; 1997

23. Terra DP. Cronologia e sequência de erupção dos dentes decíduos em crianças do município de Campo Grande, Estado do Mato Grosso do Sul [tese de mestrado]. São Paulo (SP): USP, 1999.

24. Brandão CF, Rocha MC. Cronologia e sequência de erupção dos dentes decíduos em crianças de 0 a 42 meses. JBP Rev Ibero-am Odontopediatr Odontol Bebê 2004;7:528-35. 